\title{
Disporella guada sp. nov., an erect-ramose rectangulate cyclostome (Bryozoa, Stenolaemata) from the Caribbean Sea: convergent evolution in bryozoan colony morphology
}

\author{
Paul D. TAYLOR ${ }^{\circledR 1}{ }^{1, *}$, Jean-Georges HARMELIN ${ }^{2}$, \\ Andrea WAESCHENBACH ${ }^{\circ}{ }^{3} \&$ Claude BOUCHON ${ }^{4}$ \\ ${ }^{1}$ Department of Earth Sciences, Natural History Museum, Cromwell Road, London SW7 5BD, UK. \\ ${ }^{2}$ Aix-Marseille University, Mediterranean Institute of Oceanography (MIO) \& GIS Posidonie, \\ OSU Pytheas, Station Marine d'Endoume, F-13007 Marseille, France. \\ ${ }^{3}$ Department of Life Sciences, Natural History Museum, Cromwell Road, London SW7 5BD, UK. \\ ${ }^{4}$ EcoRécif Environnement, 17 résidence Créole, 97122 Baie-Mahault, Guadeloupe. \\ *Corresponding author: p.taylor@nhm.ac.uk \\ ${ }^{2}$ Email: jean-georges.harmelin@univ-amu.fr \\ ${ }^{3}$ Email: a.waeschenbach@nhm.ac.uk \\ ${ }^{4}$ Email: claudebouchon1@gmail.com

\footnotetext{
${ }^{1}$ urn:1sid:zoobank.org:author:7AFF2929-DF5B-46B2-94E6-B26B396CC2C8

${ }^{2}$ urn:1sid:zoobank.org:author:D11AE07A-CFD9-41EE-B3F9-6E0472150300

${ }^{3}$ urn:1sid:zoobank.org:author:619FD2CB-C2A7-4B39-AAA4-98969A871310

${ }^{4}$ urn:1sid:zoobank.org:author:F4209738-D04E-4E27-9E72-FA1F11F9BE15
}

\begin{abstract}
The taxonomy of cyclostome bryozoans is founded on characters of the skeleton, but molecular sequence data have increasingly shown that established higher taxa are not monophyletic. Here we describe the skeletal morphology of a new species from Guadeloupe (French West Indies) with erect ramose colonies consisting of long, curved zooids that are typical of the suborder Cerioporina among living cyclostomes. However, molecular evidence from nuclear ribosomal RNA genes 18S and $28 \mathrm{~S}$ places the new taxon in the suborder Rectangulata, where this colony-form has not been previously recorded. It nests firmly within the genus Disporella Gray, 1848, in a strongly supported clade that also includes Plagioecia patina (Lamarck, 1816) (Tubuliporina) and the sister taxa Doliocoitis cyanea Gordon \& Taylor, 2001 (Rectangulata) and Favosipora rosea Gordon \& Taylor, 2001 (Cerioporina). The short and robust branches of the new Guadeloupe cyclostome, here named Disporella guada Harmelin, Taylor \& Waeschenbach sp. nov., are well adapted to life in shallow rocky sites exposed to severe wave action, which appear to be its exclusive habitat.
\end{abstract}

Keywords. Lichenoporidae, growth-form, taxonomy, molecular phylogeny, evolution.

Taylor P.D., Harmelin J.-G., Waeschenbach A. \& Bouchon C. 2021. Disporella guada sp. nov., an erect-ramose rectangulate cyclostome (Bryozoa, Stenolaemata) from the Caribbean Sea: convergent evolution in bryozoan colony morphology. European Journal of Taxonomy 773: 1-18. https://doi.org/10.5852/ejt.2021.773.1507 


\section{Introduction}

In common with the dominant order of bryozoans - Cheilostomata Busk, 1852 - the taxonomy of cyclostome bryozoans has been traditionally based almost entirely on features of the calcareous skeleton. The unsatisfactory nature of cyclostome taxonomy has long been acknowledged, for example by Borg (1926) and Boardman (1983). Compared with cheilostomes which also have calcareous skeletons, the simpler skeletons of cyclostomes furnish fewer skeletal characters, and many of these characters are ecophenotypically plastic. The growth-form of colonies, particularly, may change drastically according to the local physical environment, even though growth-form has been considered a major character in the definition of some genera (e.g., Harmelin 1975, 1976; McKinney \& Jackson 1989). Soft part characters have been considered (e.g., Borg 1933; Boardman \& McKinney 1985), but they seem also to be limited in number and are not easily studied, although methods such as confocal laser scanning microscopy (CLSM) are beginning to offer promise for future research (e.g., Schwaha et al. 2018).

Substantial discordance between molecular trees and traditional classifications have further questioned the value of skeletal characters in cyclostome taxonomy. It has been customary to recognize five living suborders of cyclostomes: Tubuliporina Milne Edwards, 1838, Articulata Busk, 1859, Cerioporina von Hagenow, 1851, Rectangulata Waters, 1887 and Cancellata Gregory, 1896 (e.g., Taylor 2000; Taylor \& Weedon 2000). In an early study based on nuclear ribosomal RNA genes $18 \mathrm{~S}$ and $28 \mathrm{~S}$ and including 22 cyclostome species, Waeschenbach et al. (2009) found two of these suborders - Tubuliporina and Cerioporina - to be polyphyletic. Three major molecular clades were recovered, each containing species that had traditionally been placed in two or three different suborders. Subsequent inclusion of additional taxa into this phylogenetic framework has revealed further discordance between skeletal morphology and molecules. The unusual South African cyclostome Tennysonia Busk, 1867 has a skeletal structure reminiscent of cerioporines which have kenozooids acting as spacers between the autozooids. In spite of this, Tennysonia was found to group with the tubuliporine genus Idmidronea Canu \& Bassler, 1920 (Taylor et al. 2011). A further study which included common cyclostome species from New Zealand recovered a totally unexpected clade comprising a mixture of tubuliporines and cerioporines (Taylor et al. 2015), while molecular sequencing of the jointed cyclostome Crisulipora Robertson, 1910 showed it to be unrelated to the order Articulata in which it had been previously placed (Taylor \& Waeschenbach 2019).

Here, we describe a new species of cyclostome from Guadeloupe in the Caribbean Sea which, on the basis of the ramose erect colony with an axial endozone surrounded by a cortical exozone, appears to belong to the suborder Cerioporina. However, our molecular analysis shows that it nests within the suborder Rectangulata, hitherto believed to comprise mostly encrusting taxa. The molecular phylogenetic placement of the new species allows it to be assigned to the genus Disporella Gray, 1848, the diagnosis of which is accordingly revised.

\section{Material and methods}

All specimens were collected by SCUBA diving (CB collection) at Guadeloupe (French West Indies) during two surveys in shallow waters around the 'Tête à l'Anglais' islet. This small volcanic islet is located north of Basse-Terre, in the adjacent marine part of the National Park of La Guadeloupe. The same bryozoan species was previously observed (CB) in the 1980 s at Saintes Island $\left(15^{\circ} 32.671^{\prime} \mathrm{N}\right.$, $061^{\circ} 35.140^{\prime} \mathrm{W}$ ) in a similar habitat. Collected specimens were dried or preserved in ethanol. Selected specimens were cleaned with sodium hypochlorite for examination with stereoscopic microscopes and scanning electron microscopes (SEM). SEM observations were made at the Station Marine d'Endoume, Marseille on coated specimens using an Hitachi S570, and at the Natural History Museum, London on uncoated specimens using a LEO 1455VP. Measurements were made using the eyepiece micrometer of a binocular microscope, from SEM images calibrated with scale bars, or directly from colonies. 


\title{
Molecular analysis
}

Nuclear ribosomal RNA genes 18S and 28S were sequenced for Disporella guada Harmelin, Taylor \& Waeschenbach sp. nov. and Doliocoitis cyanea Gordon \& Taylor, 2001. DNA extractions, PCRs and sequencing of $18 \mathrm{~S}$ and $28 \mathrm{~S}$ rRNA genes followed the methodology given in Waeschenbach et al. (2009). Newly generated sequences were aligned with published data (see Fig. 6 for GenBank accession numbers) using MAFFT ver. 7.453 (Katoh \& Standley 2013) applying the genafpair algorithm with 1000 cycles of iterative refinement. Ambiguously aligned positions were identified using Gblocks ver. $91 \mathrm{~b}$ online server (http://molevol.cmima.csic.es/castresana/Gblocks_server.html; Castresana 2000; Talavera \& Castresana 2007) applying the least stringent settings (allow smaller final blocks, allow gap positions within the final blocks, allow less strict flanking positions). Gblocks inclusion sets were reversed into exclusion sets using Mesquite ver. 3.51 (Maddison \& Maddison 2009). The concatenated 18S + 28S rDNA alignment, indicating the exclusion set, is available on the Natural History Museum data portal at https://doi.org/10.5519/agx $96 \mathrm{hyn}$ (Natural History Museum 2021). MrModeltest ver. 2.4 (Nylander 2004) was used in conjunction with PAUP* ver. 4.0 (Swofford 2002) to select models of nucleotide evolution. Bayesian phylogenetic analyses were carried out on the concatenated 18S $+28 \mathrm{~S}$ rDNA dataset using MrBayes ver. 3.6.2 (Ronquist et al. 2012) under the model GTR $+\mathrm{I}+\Gamma$. The alignment was partitioned by gene, and model parameters were estimated separately for each gene. Two parallel runs were performed for 10 million generations. The burnin was defined as the point at which the average standard deviation of split frequency was $<0.01$. All nodes with support $<0.95$ posterior probability (pp) were collapsed using SumTrees ver. 4.4.0 using DendroPy library ver. 4.4.0 (Sukumaran \& Holder 2010a, 2010b).

\section{Location of deposited material}

MNHN $=$ Muséum national d'histoire naturelle, Paris, France

NHMUK $=$ Natural History Museum, London, UK

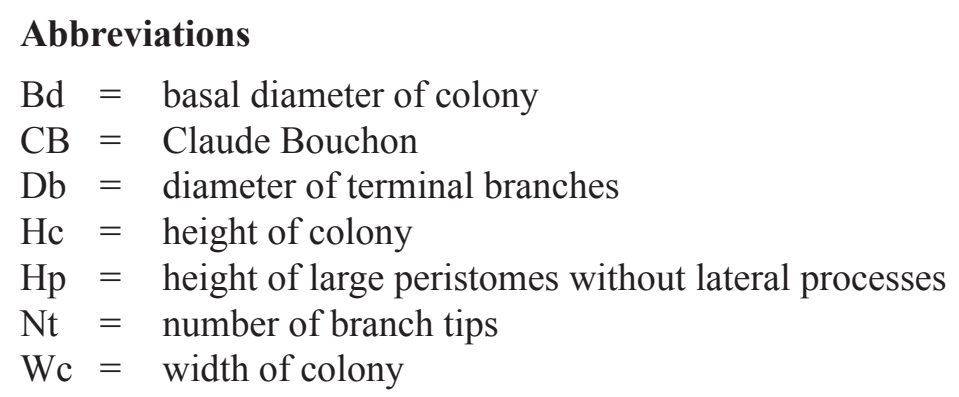

\section{Results}

Systematics

\author{
Phylum Bryozoa Ehrenberg, 1831 \\ Class Stenolaemata Borg, 1926 \\ Order Cyclostomata Busk, 1852 \\ Suborder Rectangulata Waters, 1887 \\ Family Lichenoporidae Smitt, 1867
}

Genus Disporella Gray, 1848

Disporella Gray, 1848: 138.

\section{Type species}

Discopora hispida Fleming, 1828 (Fleming 1828: 530). 


\section{Remarks}

Disporella was introduced by Gray (1848) in a list of animal specimens in the collections of the British Museum. He included only one species in the genus, albeit with several synonyms, listed by him as Tubulipora hispida. Gray (1848: 138) diagnosed Disporella thus: "Orbicular, edge thin, tubes in radiating ridges". This 'diagnosis' by itself is totally inadequate to recognise the genus. However, Fleming's (1828: 530) description of the type species (as Discopora hispida) provides some additional information: "Margin thin and waved, the cells distributed or radiated, with denticulated orifices. Coral resembling the cups and foliage of flowers.... Breadth nearly an inch; hispid, the cells seem distributed over the whole surface, and more vertical than the preceding [Discopora verrucaria]; there are, however, waved porous grooves, and the cells seem disposed on each side of these in irregular transverse rows, united or free, short, with expanding orifices, dividing into irregular spinous processes. This species is very common in Zetland [=Shetland], adhering to Cellepora cervicornis [= Smittina cervicornis (Pallas, 1766)]...”

As remarked by Alvarez (1992), there is no known holotype of Disporella hispida, nor are there any Fleming specimens from which a lectotype could be chosen. Consequently, Alvarez (1992) chose NHMUK 99.7.1.4187 as the neotype of D. hispida. This specimen is the holotype of Lichenopora mamillata Lagaaij, 1952, which Alvarez considered to be a junior synonym of D. hispida; Lagaaij (1952: 181) had introduced his new species for a form referred to by Hincks (1880) as Lichenopora hispida (Fleming) var. $\beta$. It was noted by Gordon \& Taylor (2001: 259) that the neotype chosen by Alvarez (1992) is neither topotypic - it was collected at Tenby in Wales, not the Shetland Islands almost $1000 \mathrm{~km}$ to the north - nor does it conform to the original description given by Fleming (1828) because it is not hispid (i.e., covered in spines) and the apertures (orifices) are not 'expanded'.

Stabilization of Disporella awaits comprehensive morphological description of topotype specimens matching Fleming's (1828) original description of the type species, coupled with molecular characterization. Until this is achieved, the genus name is here used as applied, for instance, by Hayward \& Ryland (1985), Alvarez (1992), and Gordon \& Taylor (2001).

Disporella guada Harmelin, Taylor \& Waeschenbach sp. nov. urn:lsid:zoobank.org:act:E6E2D7BF-A429-4ABE-B91F-4D33DE70D033

Figs $1-5$

\section{Differential diagnosis}

Disporella with erect, ramose colonies up to at least $30 \mathrm{~mm}$ in width and height; branches short and thick; branch axes constituting an endozone formed by proximal parts of zooids oriented parallel to branch axis, surrounded by an exozone formed by the distal parts of these zooids bent to become oriented at right angles to the axis; maculae circular to elongate in outline, comprising kenozooids. Autozooids with multiple apertural spines, the aperture often closed by a calcified diaphragm containing a central lumen. Gonozooid irregularly ramifying, the interior-walled roof rapidly concealed by a honeycomb of secondary calcification; ooeciopores at distal ends of lobes, occasionally paired, rounded quadrangular, without an ooeciostome.

\section{Etymology}

From Guadeloupe, the type locality.

\section{Material examined}

\section{Holotype}

FRENCH WEST INDIES, GUADELOUPE - the largest collected spec. (Figs 1A, 2A) (kept dry, Hc 28 mm, Wc 38 mm, Bd 5.4-6.2 mm, Db 2.3-3.6 mm, Hp 320-500 $\mu \mathrm{m}$, Nt 26, + 3 broken tips, 
coated for SEM); Islet “Tête-à-l'Anglais”; $16^{\circ} 22.936^{\prime}$ N, $061^{\circ} 45.925^{\prime}$ W; 5 m depth; 10 Oct. 2014; CB leg.; MNHN-IB-2017-696.

\section{Paratypes}

FRENCH WEST INDIES, GUADELOUPE • 1 spec. (paratype A: Hc 20 mm, Wc 2.4 mm, Nt 8; preserved in ethanol); Islet “Tête-à-l'Anglais"; $16^{\circ} 22.916^{\prime}$ N, 061 $35.140^{\prime}$ W; 3-5 m depth; 7 Nov. 2016; CB leg.; MNHN-IB-2017-697 1 spec. (paratype B: Hc $20 \mathrm{~mm}$, Wc $16 \mathrm{~mm}$, Nt 5; preserved in ethanol); same collection data as for preceding; CB leg; MNHN-IB-2017-698 (NHMUK 2018.1.15.63 hologenophore) - 7 specs; same collection data as for preceding; NHMUK 2021.2.25.1, NHMUK 2021.3.19.1, NHMUK 2012.3.19.2, NHMUK 2021.6.14.1, NHMUK 2021.6.14.2, NHMUK 2021.6.14.3, NHMUK 2021.6.14.4.

\section{Other material}

FRENCH WEST INDIES, GUADELOUPE 11 colonies, small to medium-sized (Hc 8-15 mm) with varied shape (small: columnar, larger: ramified), preserved in ethanol; same collection data as for paratype A; MNHN-IB-2017-699-709.

\section{Morphology}

Colony white when alive (Fig. 1A-B), heavily calcified, erect, up to $30 \mathrm{~mm}$ in both height and width in collected material, rapidly and irregularly ramified in all directions from a short basal trunk, branches short and thick but variably sized, roughly cylindrical or slightly flattened, with rounded tips (Fig. 2BC); the largest colony (holotype) with 29 branch tips (Fig. 2A). Distal branch growing tips hemispherical, exposing a mixture of autozooidal and kenozooidal apertures (Fig. 2D); interzooecial walls with a broken medial ridge; spines lacking (Fig. 2E). Marginal lamina apparently absent at the base of colonies (juvenile specimens not seen). During growth, the base of the colony (Fig. 2C-a) can increase the diameter of its attachment surface by the downward budding of a peripheral blade apparently made of kenozooids (Fig. 2C-b).

Surface of branches occupied by autozooids and kenozooids (Figs 3B, D-E, 4A). Transverse section of branches revealing an axial endozone occupying $40-50 \%$ of the area (Fig. 3C), formed by proximal parts of zooids growing parallel to branch axis, surrounded by an outer exozone corresponding to the
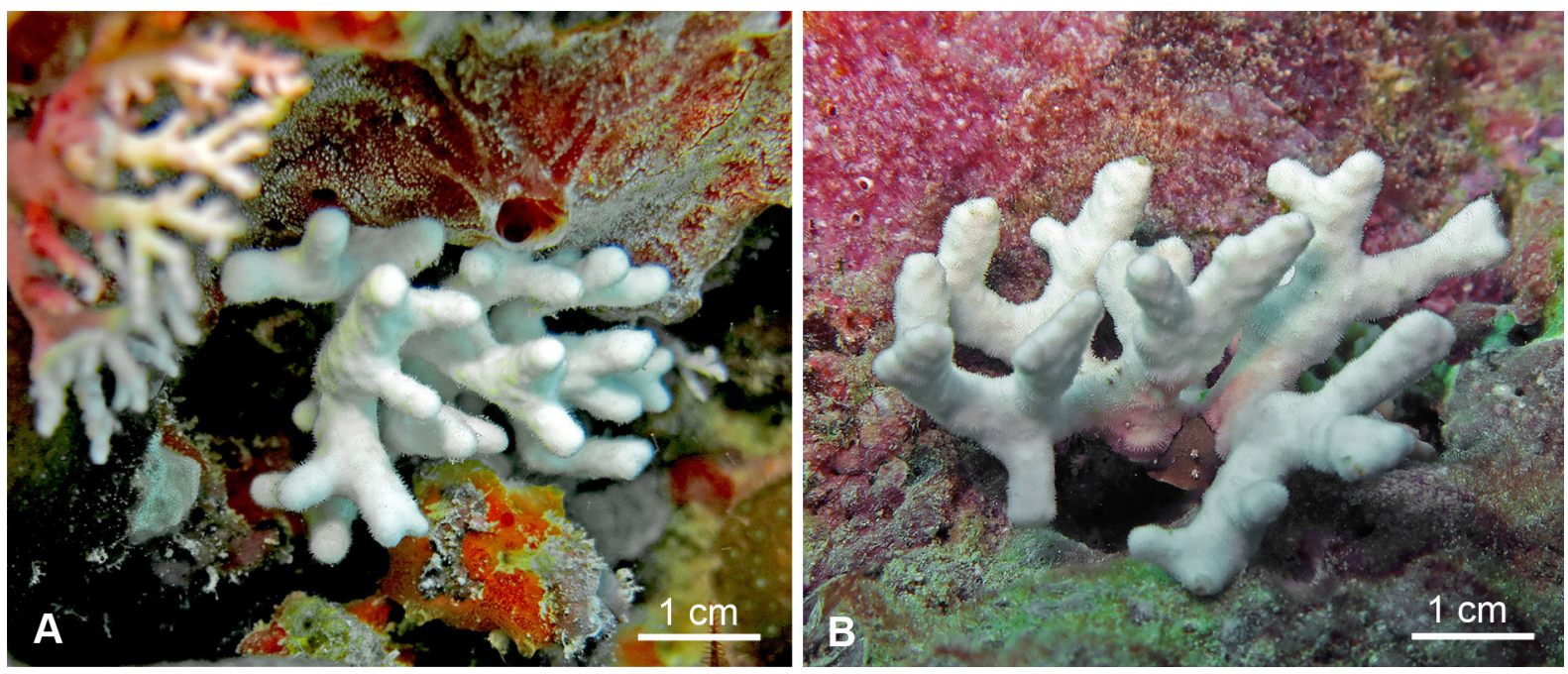

Fig. 1. Underwater photos of specimens of Disporella guada Harmelin, Taylor \& Waeschenbach sp. nov.; Guadeloupe, Islet Tête-à-l'Anglais, 5 m. A. Holotype (MNHN-IB-2017-696); photo Y. BouchonNavaro, 10 Oct. 2014. B. Another large specimen; photo C. Bouchon, 7 Nov. 2016. 


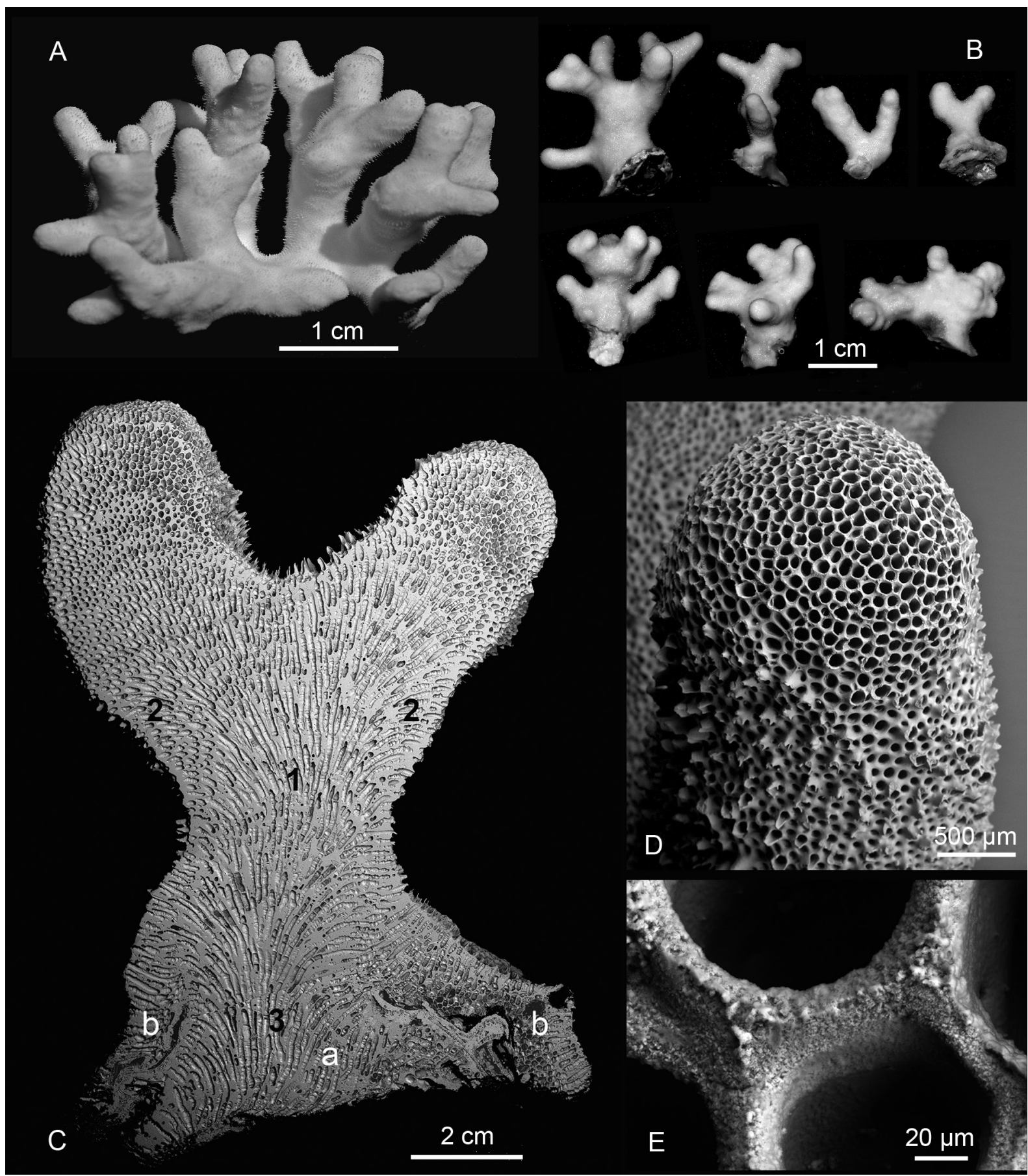

Fig. 2. Photographs (A-B) and scanning electron micrographs of Disporella guada Harmelin, Taylor \& Waeschenbach sp. nov. A. Holotype, specimen kept dry (MNHN-IB-2017-696). B. Seven variously shaped colonies (top row, left to right: NHMUK 2021.2.25.1, 2021.3.19.2, 2018.1.15.63, 2021.3.19.1; bottom row, left to right: NHMUK 2021.6.14.1, 2021.6.14.2, 2021.6.14.3). C. Longitudinal section of a specimen (NHMUK 2021.3.19.1) with two branches; 1: endozone, 2: exozone, 3: basal part with central primary attachment zone (3a) and secondary peripheral attachment zone (3b). D-E. NHMUK 2021.3.19.2. D. Growing tip. E. Interzooecial walls at growing tip. 
distal parts of these zooids bent at right angles to the branch axis (Fig. 2C). Lateral walls of zooids very thick, moniliform, with pointed mural spines or pustules (Fig. 4D-E, H) and communication pores hourglass-shaped in vertical section (Fig. 4G), originating at the surface of the colony (see below). Skeletal ultrastructure granular in appearance at growing edges, lacking a layer of transverse fibres.

Kenozooids with rounded apertures (Fig. 4A) smaller than those of the autozooids $(25-45 \mu \mathrm{m})$, occasionally associated (frequently in the largest specimen) with a single pointed process rising vertically or slightly bent (Fig. 4C), scattered between autozooids or clustered together to form maculae on the colony surface (Fig. 3B). Maculae of variable shapes and sizes, from relatively small and nearly circular to large and elongated along branches (Fig. 3A), particularly frequent near branch bifurcations.

Autozooids loosely arranged in quincunx or more irregularly, interspersed with kenozooids. Peristomes short, the largest (up to $500 \mu \mathrm{m}$ ) in the shape of a concave blade arising from the distal edge of the aperture, tip truncated (gouge-shaped) or pointed, with a large oblique opening reaching the colony surface; a pair of pointed processes lateral to the blade on medium-sized peristomes (Fig. 3E), the smallest peristomes reduced to a short, arched wall with up to 4 or 5 terminal pointed processes (Fig. 3D). Communication pores visible below the outer rim of apertures of both kenozooids and autozooids, and also in the peristomes of autozooids (Fig. 4E).

Mural spines pointed and variously sized, or short and blunt (pustules), abundant inside tubes of autozooids and kenozooids (up to 15-18 around the circumference of kenozooidal apertures) (Fig. 4A, $\mathrm{E}-\mathrm{H})$, and on the outer sides of brood chambers with fewer on the inner sides.

Calcified diaphragms present in kenozooids and in some autozooids of large (presumably old) specimens (Fig. 4B-C), subterminal, funnel-shaped, iris-like with a central lumen of varying size $(8-25 \mu \mathrm{m})$, adorally curved at contact with the interzooecial walls, a clear discontinuity visible between the outer edge of the diaphragm and these walls (Fig. 4F); a succession of diaphragms spaced 100 to $>500 \mu \mathrm{m}$ apart seen in sectioned zooids, suggesting sequential growth and resting stages.

Brood chambers irregularly ramose with narrow lateral branches (Fig. 5A), sub-circular in section (Fig. 5C), interior-walled, floor and roof formed by a thin skeletal layer, roof rapidly concealed by secondary calcification starting with a honeycomb mesh structure (Fig. 5A-B); outer surface of overgrowths densely dotted with large pores soon closed by a calcified diaphragm inserted below the surface, inner surface smooth or with small pustules. Ooeciopore at distal end of lobes, occasionally paired (i.e., two ooeciopores are present in the same lobe) (Fig. 5D), widely open, more or less quadrangular with rounded corners, the upper edge corresponding to the boundary of the brood chamber; ooeciostome lacking.

\section{Remarks}

This new species of Disporella is distinguished from all others in the genus by its erect colony-form with bifurcating branches. It was initially believed to be a species of Doliocoitis Buge \& Tillier, 1977, regarded as a cerioporine by these authors but which has an interior-walled gonozooid as noted by Gordon \& Taylor (2001) and is therefore a rectangulate. The type species of this genus, Doliocoitis atlantica Buge \& Tillier, 1977 from the Gulf of Guinea, has a semi-erect colony with claviform branches that do not bifurcate, whereas a second species, Doliocoitis cyanea Gordon \& Taylor, 2001 from New Zealand, has encrusting colonies. A morphological comparison between Disporella guada sp. nov., Doliocoitis atlantica and Doliocoitis cyanea is presented in Table 1. A key difference between Disporella guada sp. nov. and the two species of Doliocoitis is the erect bifurcating colony-form of Disporella guada sp. nov., the branches comprising an axial endozone surrounded by an exozone. However, the structure of the basal part of the sectioned colony of D. guada sp. nov. (Fig. 2C), with secondary downward 

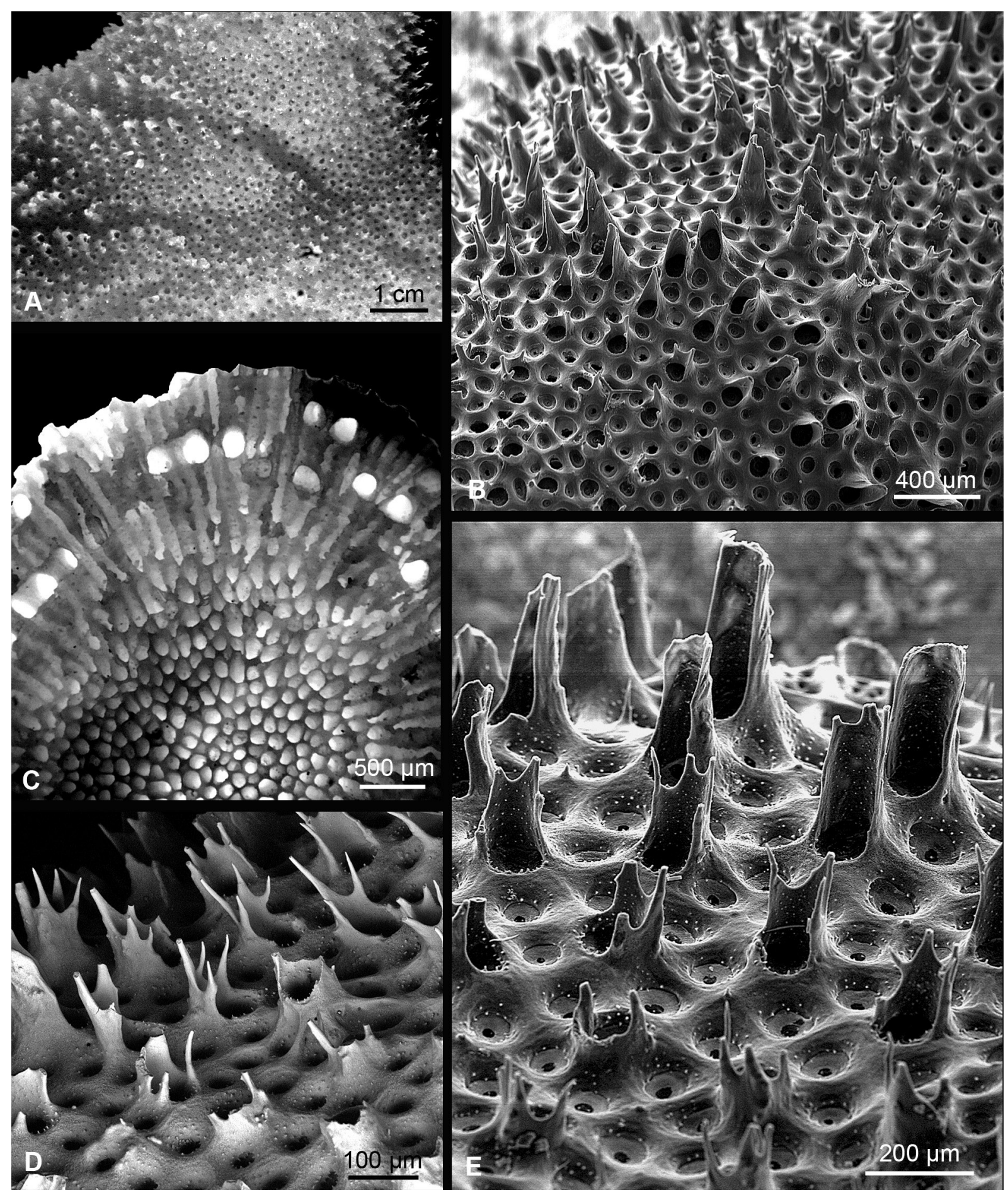

Fig. 3. Disporella guada Harmelin, Taylor \& Waeschenbach sp. nov. A. Non-type (MNHN-IB-2017-700). B-C, E. Holotype (MNHN-IB-2017-696). D. Paratype (NHMUK 2021.2.25.1). A. Elongated maculae. B. Mixture of peristomate autozooids and kenozooids. C. Part of a transverse section of a terminal branch showing the endozone, exozone and intersecting ramifications of several gonozooids (larger white cavities). D. Kenozooids and autozooids with small peristomes bearing pointed processes. E. Kenozooids and autozooidal peristomes of various sizes and shapes. 


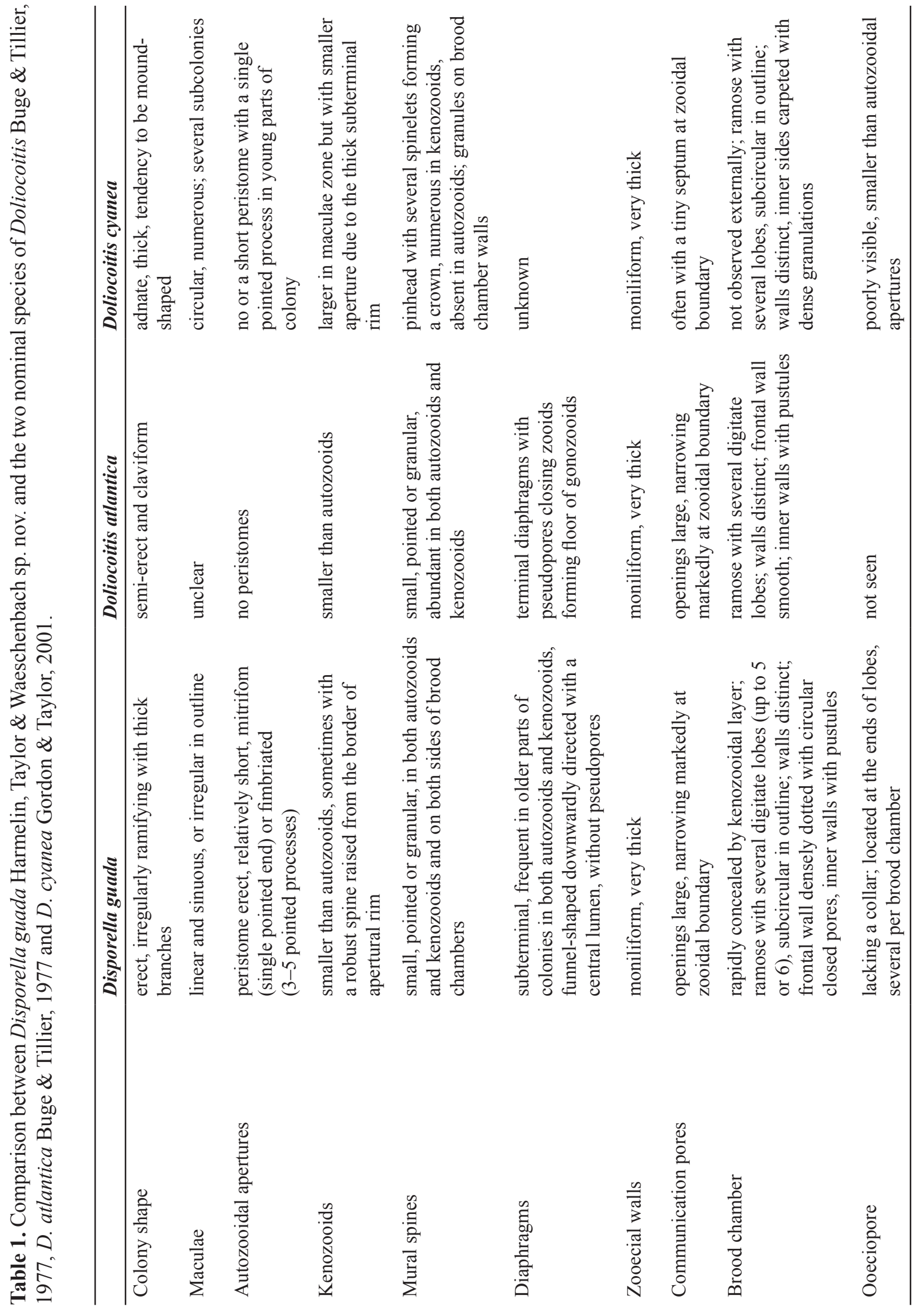


growth of a peripheral blade, matches with the process of basal thickening in Doliocoitis atlantica described and figured by Buge \& Tillier (1977: 6, fig. 2). Doliocoitis lacks the prominent interior-walled peristomial spines that characterize Disporella guada sp. nov., although the apertural rims in Doliocoitis cyanea do have short processes on one side.

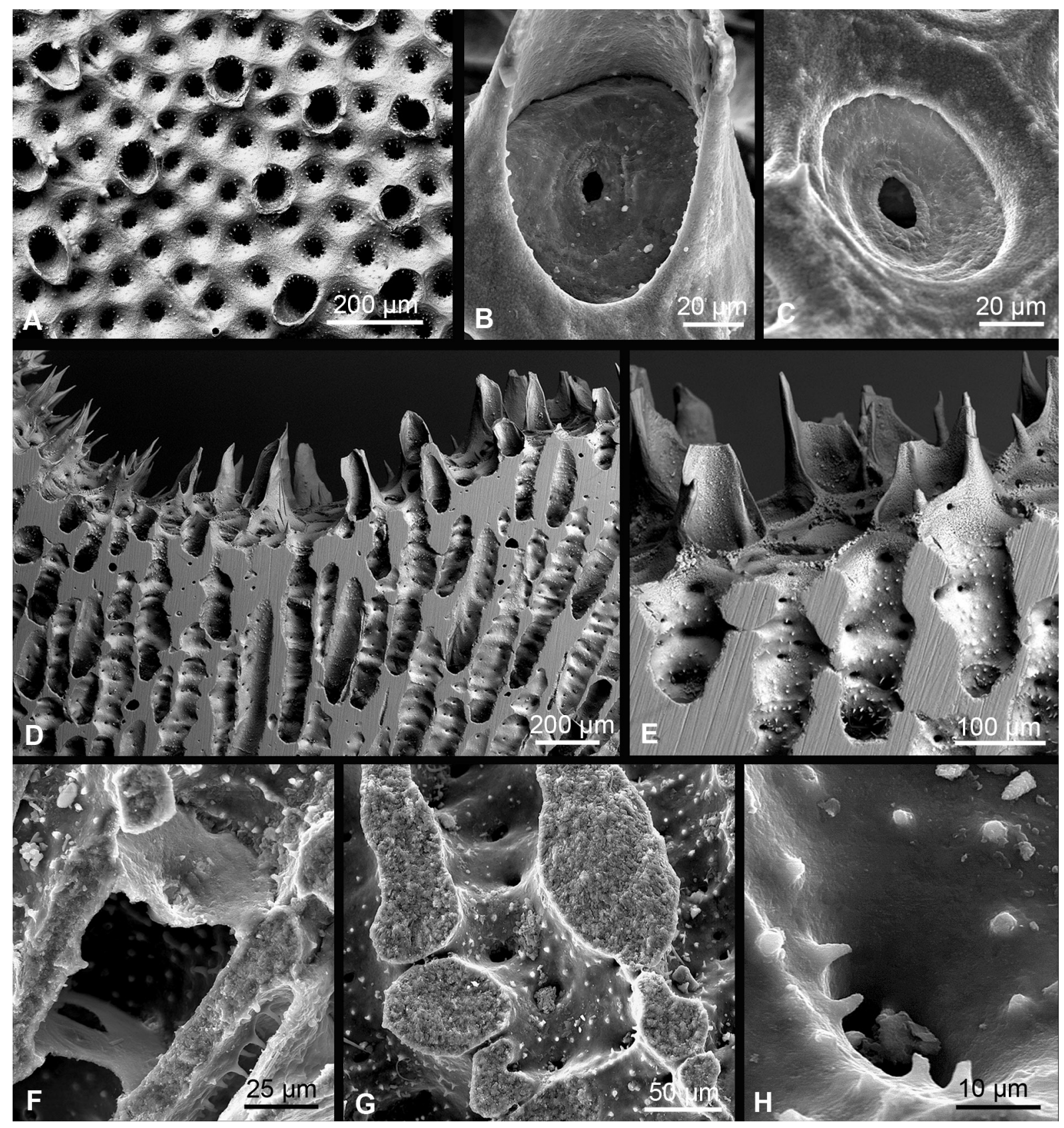

Fig. 4. Disporella guada Harmelin, Taylor \& Waeschenbach sp. nov. A. Paratype (NHMUK 2021 2.25.1). B-C, F-H. Holotype (MNHN-IB-2017-696). D-E. Paratype (NHMUK 2021.3.19.1). A. Frontal view of autozooids with short peristomes interspersed with kenozooids. B-C. Calcified diaphragms with a central lumen closing an autozooid (B) and a kenozooid (C). D-E, G. Longitudinal sections of zooids showing the moniliform walls with mural pustules, and the communication pores. F. Funnel-shaped diaphragm with a sectioned autozooid. H. Mural spines and pustules surrounding a communication pore. 


\section{Habitat and colony shape}

Disporella guada sp. nov. was found at two sites in the French West Indies characterised by the same general environmental conditions, i.e., very shallow depth $(3-5 \mathrm{~m})$ and exposure to strong wave action. Variously sized colonies of D. guada sp. nov. grow on the shadowed side of rocks together with sponges, hydroids, gorgonians, and the stylasterid Stylaster roseus (Pallas, 1766), but apparently without large macrophytes. The highly robust colonies of this erect species, owing to small size and very thick trunk and branches, seem well adapted to life in a high-energy flow regime. In the largest and most profusely ramified colony collected (the holotype), the ratio of colony height $(28 \mathrm{~mm}$ ) to mean branch width $(3.5 \mathrm{~mm})$ is particularly low (8). This ratio contrasts with the very high values seen, for example, in large colonies of branched cheilostomes inhabiting conditions of reduced flow, such as in caves. The finding of $D$. guada sp. nov. only in high flow regimes where colonies are stocky raises the question of whether it is specialized for this particular habitat. Many species of cyclostomes exhibit considerable plasticity in

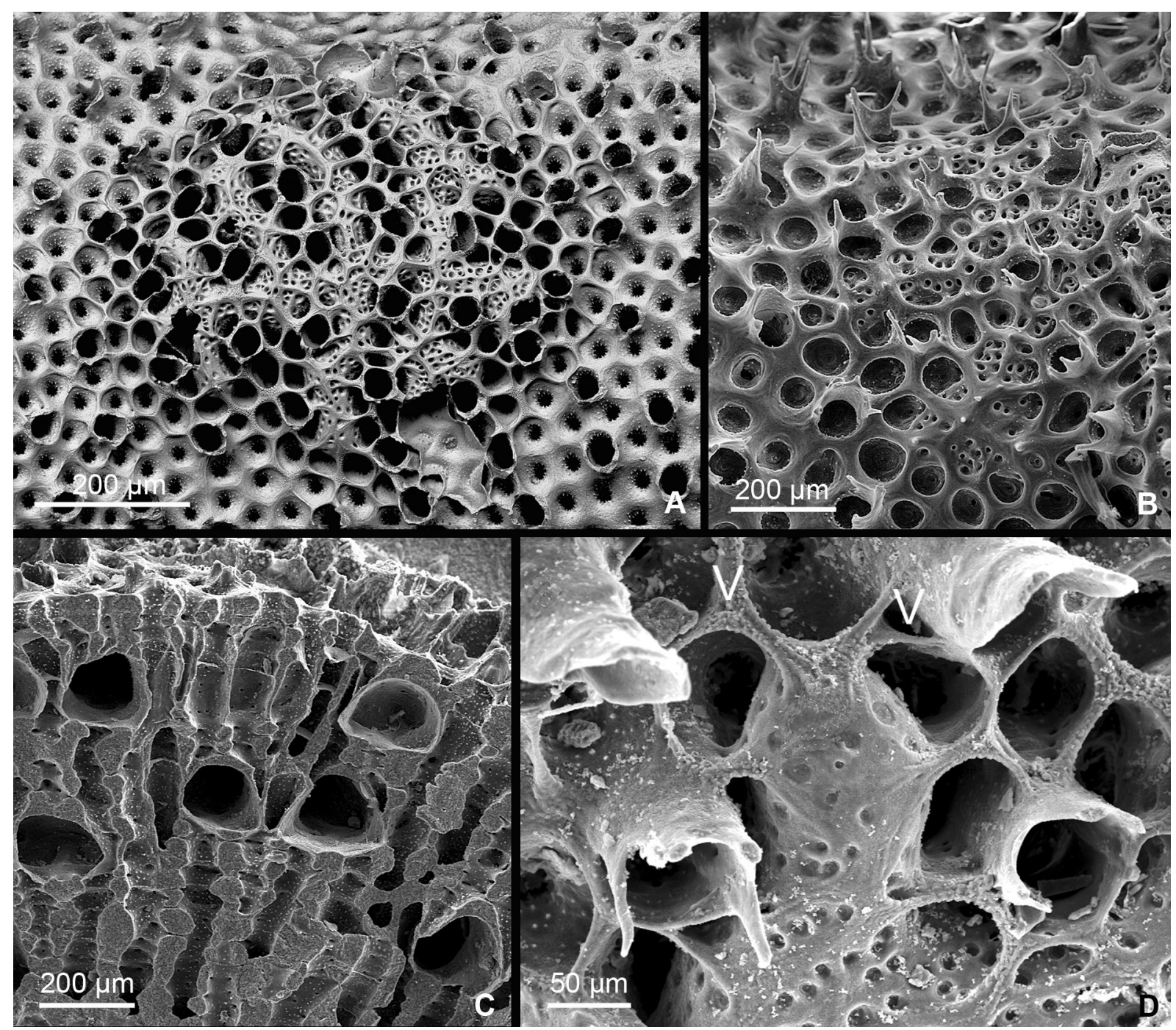

Fig. 5. Brood chambers in Disporella guada Harmelin, Taylor \& Waeschenbach sp. nov. A. Paratype (NHMUK 2021.2.25.1). B-D. Holotype (MNHN-IB-2017-696). A. Brood chamber with 8 lateral branches, thinly covered by secondary calcification. B. Thicker mesh of secondary calcification over a brood chamber. C. Transverse section of branch intersecting six lobes of ramifying brood chambers. D. Two ooeciopores (open arrowheads) at the end of a lateral branch of a brood chamber. 
colony form according to the microenvironment inhabited (Harmelin 1975, 1976). Therefore, it cannot be ruled out that $D$. guada sp. nov. is present also in other unexplored microhabitats - such as the undersides of boulders, in cavities or in deeper water - where the shape of the colonies may be different.

\section{Molecular phylogeny}

Previous studies on cyclostome phylogenetics have revealed several unexpected results (Waeschenbach et al. 2009; Taylor et al. 2011, 2015; Taylor \& Waeschenbach 2019), which is why the newly generated data were analysed in the broader context of cyclostome phylogeny (Fig. 6). Bayesian inference places D. guada sp. nov. firmly in the genus Disporella (Rectangulata), in a strongly supported clade that also includes Plagioecia patina (Tubuliporina) and sister taxa Doliocoitis cyanea (Rectangulata) and Favosipora rosea Gordon \& Taylor, 2001 (Cerioporina). The remainder of the phylogeny largely corresponds to previous versions, except reduced nodal support $(0.89 \mathrm{pp})$ for a sister-group relationship of Crisia spp. and the remainder of Clade C in Waeschenbach et al. (2009), and a switch in positions between Annectocyma tubulosa (Busk, 1875) and Heteropora sp. 1 compared to the topology presented by Taylor et al. (2015) and Taylor \& Waeschenbach (2019).

\section{Discussion}

In spite of its ramose erect colony, Disporella guada sp. nov. resides within a clade of otherwise entirely encrusting cyclostomes in the molecular tree (Fig. 6). It is the sister-species of Disporella hispida, the type species of the rectangulate genus Disporella. The absence of a Doliocoitis $+D$. guada grouping supports morphological observations outlined in the Remarks section that distinguish the two genera. The clade containing D. guada sp. nov. is equivalent to 'Clade A' of Waeschenbach et al. (2009). Identifying persuasive morphological apomorphies for this clade is difficult as it contains genera with a mixture of skeletal traits, notably: (1) genera with free-walled autozooids separated by kenozooids (e.g., Disporella, Doliocoitis, Favosipora MacGillivray, 1885) as well as genera with fixed-walled autozooids but no kenozooids (Plagioecia Canu, 1918); (2) genera having free-walled gonozooids with roofs consisting of interior wall calcification (Disporella, Doliocoitis), as well as genera having fixed-walled gonozooids with roofs of exterior wall calcification (Favosipora, Plagioecia); and (3) genera having protoecia with a single marginal row of pseudopores (Plagioecia) as well as those lacking pseudopores (Disporella) (Jenkins \& Taylor 2017). Only the absence of seminacre/pseudofoliated fabric in the skeleton was identified as a potential apomorphy of Clade A (Waeschenbach et al. 2009); this fabric is also lacking in D. guada sp. nov.

The overwhelming majority of lichenoporid and other rectangulate cyclostome species have encrusting colonies. These may be cemented to the substrate over the entire area of the basal lamina. Sometimes the basal lamina lifts off the substrate during growth around the outer edges of the colony (e.g., Taylor 2020: fig. 5.4b), seemingly to form a defensive rampart hindering overgrowth by competitors for substrate space (Stebbing 1973). Encrusting colonies initially consist of a single disc or low dome, but larger colonies may be compound, comprising an aggregate of dome-shaped subcolonies (e.g., Hayward \& Ryland 1985: fig. 46b; Gordon \& Taylor 2001: fig. 41). The ability of rectangulates to produce subcolonies also provides them with a means of achieving erect growth by stacking the subcolonies one on top of the other (e.g., Gordon \& Taylor 2001: fig. 33). Among living rectangulates, these colonies may be massive, consisting of multiple layers of subcolonies, as in the un-named species figured by Taylor (2020: pl. 8 fig. h). Unlike $D$. guada sp. nov, however, they are not known to produce ramose, branched colonies. The Recent species Coronopora truncata (Fleming, 1828), which was classified in Lichenoporidae by Hayward \& Ryland (1985), is unusual in its ramose colonies formed of bifurcating stacks of subcolonies. However, Voigt (1975) showed this northwest European species to possess exterior-walled autozooids and gonozooids. The arrangement of the autozooidal apertures in radial fascicles on the upper surfaces of the subcolonies prompted Voigt to place Coronopora Gray, 1848 in the tubuliporine family 


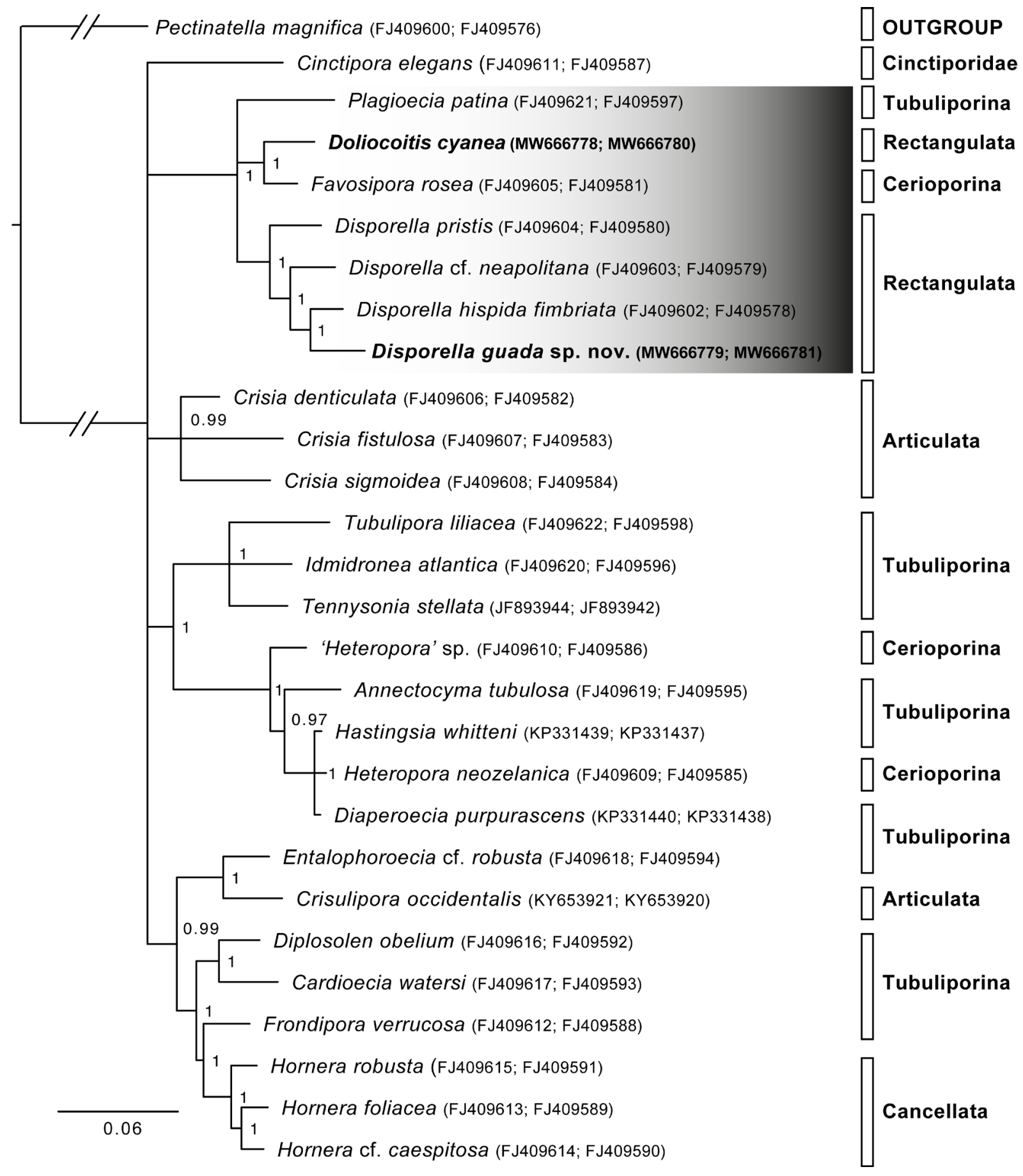

Fig. 6. Bayesian analysis of the concatenated $18 \mathrm{~S}+28 \mathrm{~S}$ rDNA dataset constructed using MrBayes ver. 3.6.2 under the GTR $+\mathrm{I}+\Gamma$ model of nucleotide evolution. The analysis was run for 10 million generations; 7 million generations were discarded as burn-in. Posterior probabilities are given at the nodes. All nodes with $<0.95$ posterior probabilities have been collapsed. The branch length scale bar indicates number of substitutions per site. Higher level classification is given at the right-hand side. Emboldened terminals indicate newly generated data. 
Theonoidae Busk, 1859. Regardless of its family assignment, there is no reason to consider Coronopora as a rectangulate cyclostome in the traditional concept of this suborder and molecular sequence data is needed to ascertain its relationships with other cyclostome genera. Therefore, the erect ramose colonyform of $D$. guada sp. nov. is currently unique among living rectangulates.

Erect growth in D. guada sp. nov. is achieved not by stacking dome-shaped subcolonies but by an alternative method commonly employed by bryozoans with ramose colonies. In this mode of growth, most or all zooids are budded close to the centres of the branches and have their long axes initially oriented parallel to the branch before bending through approximately $90^{\circ}$, diverging from the branch axis, and opening around the circumference of the branch. The centre of the branch constitutes an 'endozone' formed of the proximal parts of the zooids. This is surrounded by an 'exozone' formed of their distal parts. Branch lengthening is accomplished by budding and growth of zooids in the endozone, whereas branch thickening is achieved by growth of zooids in the exozone. Progressive decrease in the rate of skeletal growth from the endozone into the exozone and its eventual cessation is responsible for the cylindrical shape of the branches. The transition between endozone and exozone in D. guada sp. nov. is gradual and lacks the conspicuous thickening of the skeletal walls in the exozone seen in many bryozoans with this growth pattern. The success of this growth pattern is evident in its wide taxonomic distribution through the long geological history of bryozoans. It is first known in the Early Ordovician trepostome Orbiramus Xia et al., 2007, characterizes a wealth of Palaeozoic-Recent stenolaemate bryozoan genera, and is also found in some cheilostomes such as Chiplonkarina Taylor \& Badve, 1995. Among Recent cyclostomes, this growth pattern is particularly associated with species traditionally assigned to the cerioporine genus Heteropora Blainville, 1830, or occasionally to Tetrocycloecia Canu, 1917. Both of these genera have fossil type species (see Nye 1976) and the correct generic assignment for Recent 'heteroporid' species (e.g., Busk 1879; Nicholson 1880; Waters 1880; Borg 1933; Osburn 1953; Moyano 1973; Ross 1973; Taylor et al. 1989; Ernst 2021) has yet to be adequately resolved (Taylor et al. 2015: 532).

Notwithstanding this nomenclatural issue, ramose erect colonies of Disporella guada sp. nov. bear a greater overall resemblance to Recent species placed in Heteropora than they do to other species of Disporella. Yet, molecular evidence unequivocally places this new species within the Disporella clade. Are there any skeletal characters supporting this phylogenetic relationship over a closer affinity with Heteropora? The most striking character is the presence of spinose or cuspate interior-walled 'peristomes' in D. guada sp. nov. These are present in other species of Disporella, in which they have also been termed apertural spines (Taylor et al. 1995) or pseudolunaria (Brood 1972), but not in heteroporids where peristomes are exterior-walled, pseudoporous, tubular structures with straight distal edges (Taylor et al. 2015: fig. 45). The interior-walled roof of the gonozooid in D. guada sp. nov. resembles that seen in other species of Disporella (e.g., Gordon \& Taylor 2001: figs 25, 28, 40, 50). In contrast, the gonozooids of heteroporids have exterior-walled roofs as in ' $H$ '. neozelanica (Busk, 1879) (Taylor et al. 2015: fig. 42) and H. alaskensis Borg, 1933 (Osburn 1953: pl. 73 fig. 10), although Borg (1933: text-fig. 29) portrayed some Heteropora brood chambers seemingly lacking a calcified roof. Skeletal ultrastructure has been described in only a few species of rectangulate cyclostomes (Taylor et al. 1995) as well as three species assigned to Heteropora (Weedon \& Taylor 1996). The dominant ultrastructural fabric making up the walls of the rectangulates plus one of the heteroporids (H. magna O'Donoghue \& O'Donoghue, 1923) consists of distally imbricated, foliated crystallites; lacking in all of these taxa are transverse fibres, which are widespread among cyclostomes and occur in several other heteroporids (Taylor \& Weedon 2000) including species assigned to molecular Clade C of Waeschenbach et al. (2009). While a thorough study of the skeletal ultrastructure of D. guada sp. nov. has not been undertaken, low-resolution scanning electron micrographs show that it too lacks transverse fibres. Finally, the funnel-shaped diaphragms with central lumens found in D. guada sp. nov. have a much greater similarity to those described in a congener, D. ezoensis Taylor \& Grischenko, 2015 (Taylor \& Grischenko 2015: fig. 3d) from Japan, 
than to the exterior-walled, pseudoporous diaphragms found among heteroporids (e.g., Borg 1933: textfig. 4; Taylor et al. 2015: fig. 40).

In conclusion, the discovery of a new species of Disporella with ramose colonies provides yet another example of convergent evolution among bryozoans (see Taylor 2020: chapter 9.11) and expands the morphological disparity known in the cyclostome suborder Rectangulata. Likewise, molecular Clade A of Waeschenbach et al. (2009) which previously contained only encrusting species of cyclostomes now includes the erect species D. guada sp. nov. The most recent diagnosis of Disporella (Gordon \& Taylor 2001: 258) begins: "Colony adnate; simple and radial, or compound and irregular." This must now be amended to: colony adnate or erect; simple and radial, compound and irregular, or ramose.

\section{Acknowledgements}

We thank the Natural History Museum Sequencing Unit, London, UK for conducting the Sanger sequencing, Peter B. Batson (University of Otago) for the donation of specimens of Doliocoitis cyanea, Sandrine Chenessaux (IMBE, Station Marine d'Endoume, Marseille) for help during SEM work, Yolande Bouchon-Navaro (Université de la Guadeloupe) for assistance during diving and her underwater photo of the holotype, and Mary Spencer Jones (NHMUK) for curation.

\section{Data availability}

The datasets generated during the current study are available from the corresponding authors on reasonable request.

\section{References}

Alvarez J.A. 1992. Sobre algunas especies de la familia Lichenoporidae Smitt, 1866 (Bryozoa, Cyclostomida) en la región Atlántico-Mediterránea. Parte I: género Disporella Gray, 1848. Cahiers de Biologie marine 33: 201-243.

Boardman R.S. 1983. General features of the class Stenolaemata. In: Robison R.A. (ed.) Treatise on Invertebrate Paleontology, Part G (revised): 49-137. Geological Society of America, Boulder.

Boardman R.S. \& McKinney F.K. 1985. Soft part characters in stenolaemate taxonomy. In: Nielsen C. \& Larwood G.P. (eds) Bryozoans: Ordovician to Recent: 35-44. Olsen \& Olsen, Fredensborg, Denmark.

Borg F. 1926. Studies on Recent cyclostomatous Bryozoa. Zoologiska Bidrag från Uppsala 10: 181-507.

Borg F. 1933. A revision of the recent Heteroporidae. Zoologiska Bidrag från Uppsala 14: 253-394.

Brood K. 1972. Cyclostomatous Bryozoa from the Upper Cretaceous and Danian in Scandinavia. Stockholm Contributions in Geology 26: 1-464.

Buge E. \& Tillier S. 1977. Doliocoitis atlantica n. gen. n. sp., cériopore (Bryozoa, Cyclostomata) des côtes d'Afrique occidentale. Bulletin du Muséum national d'histoire naturelle, Zoologie 295: 1-23.

Busk G. 1879. On Recent species of Heteropora. The Journal of the Linnean Society of London. Zoology 14: 724-726. https://doi.org/10.1111/j.1096-3642.1879.tb02357.x

Castresana J. 2000. Selection of conserved blocks from multiple alignments for their use in phylogenetic analysis. Molecular Biology and Evolution 17: 540-552.

https://doi.org/10.1093/oxfordjournals.molbev.a026334

Ernst A. 2021. Cyclostomata (Stenolaemata). In: Schwaha T. (ed.) Handbook of Zoology. Phylum Bryozoa: 225-263. De Gruyter, Berlin.

Fleming J. 1828. A History of British Animals. Bell \& Bradfute, Edinburgh. https://doi.org/10.5962/bhl.title.12859 
Gordon D.P. \& Taylor P.D. 2001. New Zealand Recent Densiporidae and Lichenoporidae (Bryozoa: Cyclostomata). Species Diversity 6: 243-290. https://doi.org/10.12782/specdiv.6.243

Gray J.E. 1848. List of the Specimens of British Animals in the Collections of the British Museum. Part 1. Centrionae or Radiated Animals. Trustees of the British Museum, London. https://doi.org/10.5962/bhl.title.1582

Harmelin J.G. 1975. Relations entre la forme zoariale et l'habitat chez les Bryozoaires Cyclostomes. Conséquences taxonomiques. In: Pouyet S. (ed.) Bryozoa 1974. Documents des Laboratoires de Géologie de la Faculté des Sciences de Lyon H.S. 3 (2): 369-384.

Harmelin J.G. 1976. Le sous-ordre des Tubuliporina (Bryozoaires Cyclostomes) en Méditerranée. Ecologie et systématique. Mémoires de l'Institut océanographique, Monaco 10: 1-326.

Hayward P.J. \& Ryland J.S. 1985. Cyclostome bryozoans. Keys and notes for the identification of the species. Synopses of the British Fauna. New Series 34: 1-147.

Hincks T. 1880. A History of the British Marine Polyzoa. J. Van Voorst, London. https://doi.org/10.5962/bhl.title.3978

Jenkins H.L. \& Taylor P.D. 2017. Ancestrular morphology in cyclostome bryozoans and the quest for phylogenetically informative skeletal characters. Journal of Natural History 51: 2849-2861.

https://doi.org/10.1080/00222933.2017.1388860

Katoh K. \& Standley D.M. 2013. MAFFT multiple sequence alignment software version 7: improvements in performance and usability. Molecular Biology and Evolution 30: 772-780.

https://doi.org/10.1093/molbev/mst010

Lagaaij R. 1952. The Pliocene Bryozoa of the Low Countries and their bearing on the marine stratigraphy of the North Sea region. Mededelingen van de Geologische Stichting, Serie C 5: 1-233.

Maddison W.P. \& Maddison D.R. 2018. Mesquite: a modular system for evolutionary analysis. Version 3.51.Available from http://www.mesquiteproject.org [accessed 13 Sep. 2021].

McKinney F.K. \& Jackson J.B.C. 1989. Bryozoan Evolution. The University of Chicago Press, Chicago \& London.

Moyano G.H.I. 1973. Heteropora chilensis n. sp. Nuevo heteropórido para el Pacífico sudoriental (Bryozoa Cyclostomata). Cahiers de Biologie marine 14: 79-87.

Natural History Museum. 2021. Dataset: Disporella guada sp. nov., an erect rectangulate cyclostome (Bryozoa, Stenolaemata) from the Caribbean Sea: convergent evolution in bryozoan colony morphology. Natural History Museum Data Portal. https://doi.org/10.5519/agx96hyn

Nicholson H.A. 1880. On the minute structure of the recent Heteropora neozelanica, Busk, and on the relations of the genus Heteropora to Monticulipora. Annals and Magazine of Natural History, Series 5 6: 329-339, 414-423. https://doi.org/10.1080/00222938009458950 -

https://doi.org/10.1080/00222938009458971

Nye O.B. Jr. 1976. Generic revision and skeletal morphology of some cerioporid cyclostomes (Bryozoa). Bulletins of American Paleontology 69: 1-222.

Nylander J.A.A. 2004. MrModeltest v2. Program distributed by the author. Evolutionary Biology Centre, Uppsala University. Available from https://github.com/nylander/MrModeltest2 [accessed 13 Sep. 2021].

Osburn R.C. 1953. Bryozoa of the Pacific Coast of America. Part 3, Cyclostomata, Ctenostomata, Entoprocta, and addenda. Allan Hancock Pacific Expeditions 14: 613-841.

https://doi.org/10.5962/bhl.title.6542 
Ronquist F., Teslenko M., van der Mark P., Ayres D.L., Darling A., Höhna S., Larget B., Liu L., Suchard M.A. \& Huelsenbeck J.P. 2012. MrBayes 3.2: Efficient Bayesian phylogenetic inference and model choice across a large model space. Systematic Biology 61: 539-542.

https://doi.org/10.1093/sysbio/sys029

Ross J.R.P. 1973. Calcification in the colonial stenolaemate, Heteropora. In: Larwood, G.P. (ed.) Living and Fossil Bryozoa: 475-483. Academic Press, London.

Schwaha T., Handschuh S., Ostrovsky A.N. \& Wanninger A. 2018. Morphology of the bryozoan Cinctipora elegans (Cyclostomata, Cinctiporidae) with first data on its sexual reproduction and the cyclostome neuro-muscular system. BMC Ecology and Evolution 18: 92.

https://doi.org/10.1186/s12862-018-1206-1

Stebbing A.R.D. 1973. Observations on colony overgrowth and spatial competition. In: Larwood G.P. (ed.) Living and Fossil Bryozoa: 173-183. Academic Press, London.

Sukumaran J. \& Holder M.T. 2010a. DendroPy: a Python library for phylogenetic computing. Bioinformatics 26: 1569-1571. https://doi.org/10.1093/bioinformatics/btq228

Sukumaran J. \& Holder M.T. 2010b. SumTrees: Phylogenetic Tree Summation. 4.0.0. Available at https://github.com/jeetsukumaran/DendroPy [accessed 13 Sep. 2021].

Swofford D.L. 2002. PAUP* version 4.0 b10. Phylogenetic Analysis using Parsimony (* and other Methods). Sinauer, Sunderland.

Talavera G. \& Castresana J. 2007. Improvement of phylogenies after removing divergent and ambiguously aligned blocks from protein sequence alignments. Systematic Biology 56: 564-577.

https://doi.org/10.1080/10635150701472164

Taylor P.D. 2000. Cyclostome systematics: phylogeny, suborders and the problem of skeletal organization. In: Herrera Cubilla A. \& Jackson J.B.C. (eds) Proceedings of the $11^{\text {th }}$ International Bryozoology Association Conference: 87-103. Smithsonian Tropical Research Institute, Balboa, Republic of Panama.

Taylor P.D. 2020. Bryozoan Paleobiology. Wiley Blackwell, Oxford.

Taylor P.D. \& Grischenko A.V. 2015. Two new species of heavily calcified bryozoans from the intertidal of Akkeshi Bay, Hokkaido, Japan. Journal of Natural History 49: 1763-1775.

https://doi.org/10.1080/00222933.2015.1006287

Taylor P.D. \& Waeschenbach A. 2019. Phylogenetic affinities of Crisulipora and the dual origin of branch articulation in cyclostome bryozoans. Australasian Palaeontological Memoirs 52: 155-161.

Taylor P.D. \& Weedon M.J. 2000. Skeletal ultrastructure and phylogeny of cyclostome bryozoans. Zoological Journal of the Linnean Society 128: 337-399.

https://doi.org/10.1111/j.1096-3642.2000.tb01521.x

Taylor P.D., Schembri P.J. \& Cook P.L. 1989. Symbiotic associations between hermit crabs and bryozoans from the Otago region, southeastern New Zealand. Journal of Natural History 23: 1059-1085.

https://doi.org/10.1080/00222938900770971

Taylor P.D., Weedon M.J. \& Jones C.G. 1995. Skeletal ultrastructure in some cyclostome bryozoans of the family Lichenoporidae. Acta Zoologica 76: 205-216.

https://doi.org/10.1111/j.1463-6395.1995.tb00994.x

Taylor P.D., Waeschenbach A. \& Florence W. 2011. Phylogenetic position and systematics of the bryozoan Tennysonia: further evidence for convergence and plasticity in skeletal morphology among cyclostome bryozoans. Zootaxa 3010: 58-68. https://doi.org/10.11646/zootaxa.3010.1.5 
Taylor P.D., Waeschenbach A., Smith A.M. \& Gordon D.P. 2015. In search of phylogenetic congruence between molecular and morphological data in bryozoans with extreme adult skeletal heteromorphy. Systematics and Biodiversity 13: 525-544. https://doi.org/10.1080/14772000.2015.1049673

Voigt E. 1975. Ist Domopora stellata (Goldfuss, 1862) (Bryoz. Cyclos.) = Coronopora truncata (Fleming, 1828) ein lebendes Fossil aus der Oberkreide? Zoologischer Anzeiger 195: 186-200.

Waeschenbach A., Cox C.C., Littlewood D.T.J., Porter J.S. \& Taylor P.D. 2009. First molecular estimate of cyclostome bryozoan phylogeny confirms extensive homoplasy among skeletal characters used in traditional taxonomy. Molecular Phylogenetics and Evolution 52: 241-251.

https://doi.org/10.1016/j.ympev.2009.02.002

Waters A.W. 1880. Note on the genus Heteropora. Annals and Magazine of Natural History, Series 5 6: 156-157. https://doi.org/10.1080/00222938009458909

Weedon M.J. \& Taylor P.D. 1996. Skeletal ultrastructures in some cerioporine cyclostome bryozoans. Acta Zoologica 77: 249-265. https://doi.org/10.1111/j.1463-6395.1996.tb01269.x

Manuscript received: 14 June 2021

Manuscript accepted: 24 August 2021

Published on: 27 September 2021

Topic editor: Rudy Jocqué

Desk editor: Pepe Fernández

Printed versions of all papers are also deposited in the libraries of the institutes that are members of the EJT consortium: Muséum national d'histoire naturelle, Paris, France; Meise Botanic Garden, Belgium; Royal Museum for Central Africa, Tervuren, Belgium; Royal Belgian Institute of Natural Sciences, Brussels, Belgium; Natural History Museum of Denmark, Copenhagen, Denmark; Naturalis Biodiversity Center, Leiden, the Netherlands; Museo Nacional de Ciencias Naturales-CSIC, Madrid, Spain; Real Jardín Botánico de Madrid CSIC, Spain; Zoological Research Museum Alexander Koenig, Bonn, Germany; National Museum, Prague, Czech Republic. 